\title{
PENGARUH KARAKTERISTIK KEWIRAUSAHAAN DAN INOVASI RASA TERHADAP KEBERHASILAN USAHA MIKRO PADA CV. STELLA CATERING MEDAN
}

\author{
${ }^{1}$ Mohamad Reo Bangun, ${ }^{2}$ Dedi Iskandar Batubara \\ ${ }^{1,2}$ Universitas Muslim Nusantara Al-Washliyah Medan \\ ${ }^{1}$ hammadreobangun@gmail.com, ${ }^{2}$ dediiskandar@gmail.com
}

\begin{abstract}
This study aims to determine the effect of entrepreneurial characteristics and taste innovation on the success of micro-enterprises in CV. Stella Catering Medan. This study uses a quantitative descriptive method. the population is Consumer CV. Stella Catering from October 2020 to March 2021, as many as 55 people. The sampling technique of this study used a saturated sampling technique, so that the research sample was set as many as 55 people. As for the place of this research is CV. Stella Catering which is located on Jl. Stella I No.77, Kayu Raja, Kec. Medan Tuntungan, Medan City, North Sumatra, starting from January 2021 to July 2021. The results of this study indicate that entrepreneurial characteristics partially have a positive and significant effect on the success of micro-enterprises in CV. Stella Catering Medan. Taste innovation partially has a positive and significant effect on the success of micro-enterprises. At CV. Stella Catering Medan. The value of Fcount has a positive value of $53.421>$ Ftable $=2.78$ and a significance of $0.000<0.05$. This means that the characteristics of entrepreneurship and taste innovation simultaneously have a positive and significant effect on the success of micro-enterprises at $C V$. Stella Catering Medan. The value of Adjusted $R$ Square $(R 2)$ is 0.660, indicating that the characteristics of entrepreneurship and taste innovation explain their effect on business success, which is 0.660 or $66 \%$, while the remaining $34 \%$ is explained by other variables not examined in this study.
\end{abstract}

Keywords : Characteristics of Entrepreneurship, Taste Innovation, Business Success.

ABSTRAK : Penelitian ini bertujuan untuk mengetahui pengaruh karakteristik kewirausahaan dan inovasi rasa terhadap keberhasilan usaha mikro pada CV. Stella Catering Medan. Penelitian ini menggunakan metode deskriptif kuantitatif. yang menjadi populasi adalah Konsumen CV. Stella Catering dari bulan Oktober 2020 sampai dengan bulan Maret 2021 yaitu sebanyak 55 orang. Teknik penarikan sampel penelitian ini menggunakan teknik sampling jenuh, sehingga sampel penelitian ditetapkan sebanyak sebanyak 55 orang. Adapun yang menjadi tempat penelitian ini adalah CV. Stella Catering yang berlokasi di Jl. Stella I No.77, Kayu Raja, Kec. Medan Tuntungan, Kota Medan, Sumatera Utara, yang dimulai dari dari bulan Januari 2021 sampai dengan Juli 2021. Hasil penelitian ini menunjukkan bahwa Karakteristik kewirausahaan secara parsial berpengaruh positif dan signifikan terhadap keberhasilan usaha mikro Pada CV. Stella Catering Medan. Inovasi rasa secara parsial berpengaruh positif dan signifikan terhadap keberhasilan usaha mikro Pada CV. Stella Catering Medan. Nilai Fhitung bernilai positif sebesar 53,421 > Ftabel $=2,78$ dan signifikansi 0,000 $<0,05$. Artinya karakteristik kewirausahaan dan inovasi rasa secara simultan berpengaruh positif dan signifikan terhadap keberhasilan usaha mikro Pada CV. Stella Catering Medan. Nilai Adjusted R Square (R2) adalah 0,660 menunjukkan bahwa karakteristik kewirausahaan dan inovasi rasa menjelaskan pengaruhnya terhada keberhasilan usaha yaitu sebesar 0,660 atau 66\%, sedangkan sisanya 34\% dijelaskan oleh variabel lain yang tidak diteliti dalam penelitian ini.

Kata Kunci : Characteristics of Entrepreneurship, Taste Innovation, Business Success. Entrepreneurship. 


\section{Pendahuluan}

Karakteristik kewirausahaan pada umumnya akan menunjukkan tingkat keahlian seseorang dalam memimpin dan mengambil setiap kebijakan-kebijakan penting dalam menjalankan usaha serta kemampuannya dalam menjalin hubungan dan menarik minat kerjasama para relasi bisnis. Karakteristik wirausaha yang merupakan faktor internal dapat menentukan kesuksesan usaha menunjuk pada karakter-karakter seperti memiliki semangat tinggi, memiliki keinginan untuk berinovasi, selalu menerima tanggung jawab dengan sebaik mungkin, ingin berprestasi dan berani mengambil risiko (Dwiastanti dan Mustapa, 2020:230). Sehingga Karakteristik kewirausahaan menjadi bagian penting yang tidak bisa terpisahkan dalam seorang pengusaha karena dengan memiliki karakter ia akan lebih mudah menguasai dan menghadapi segala kemungkinan kondisi yang akan dihadapi. Bahri dan Arda (2019:266) mengungkapkan bahwa Karakteristik wirausaha adalah ciri-ciri pribadi dan keterampilan yang merupakan kompetensi wirausahawan yang diperlukan untuk mencapai keberhasilan. Maka dari itu, karakteristik wirausaha yang dimiliki seorang pengusaha akan mampu menentukan kebehasilannya dalam menjalankan dan mengembangkan usaha yang dibangunnya.

Selain karakteristik kewirausahaan, inovasi juga menjadi salah satu faktor keberhasilan usaha. Untuk dapat meraih pangsa pasar, pelaku usaha harus dapat melihat dan menilai orientasi pasar, melakukan inovasi terhadap produkproduk andalannya sehingga memiliki nilai tambah dan dapat menambah keungulan bersaing. Kemampuan berinovasi sangat perlu dimiliki oleh pelaku usaha dalam menjalankan bisnisnya karena dengan kemampuan berinovasi ia akan mudah dalam menghasilkan ide dan kreasi baru yang pasatinya berbeda dari produk- produk yang lain. Melalui kemampuan berinovasi akan memunculkan bebragai produk baru yang pastinya berbeda dengan para pesaing, baik dari bentuk rasa maupun kualitas produk itu sendiri sehingga mampu dalam menarik minat konsumen untuk membeli/menggunakan produk/jasa yang ditawarkan. Secara umum inovasi merupakan sesuatu yang dapat dilihat sebagai kemajuan fungsional produk yang dapat membawa produk selangkah lebih maju dibandingkan dengan produk pesaingnya. Produk yang memiliki kelebihan memiliki nilai tambah bagi konsumen (Wiranwati, 2017:4). Oleh karena itu, inovasi dianggap salah satu mesin yang paling penting bagi keberhasilan usaha, karena inovasi yang sukses dapat mendorong wirausahawan untuk menjadi lebih baik di bidangnya di masa yang akan datang.

I CV. Stella Catering Medan yang merupakan usaha bersakala mikro yang bergerak di bidang kuliner (katering). CV. Stella Catering merupakan konsep catering makanan yang bertempat di daerah Kota Medan. Catering ini menawarkan menu makanan yang dapat menggugah selera konsumen. Menu yang disediakan dari CV. Stella Catering berupa olahan ayam, ikan, sayuran, seafood, daging sapi atau kambing. CV. Stella Catering adalah salah satu jasa di bidang makanan yang telah diolah dan dapat diantar langsung ke tempat pemesanan. CV. Stella Catering ini saat ini melayani berbagai kebutuhan konsumsi pada event- event besar pernikahan, syukuran, tumpeng dan pesanan-pesanan lainnya.

Menurut hasil pra riset langsung dari tempat penelitian diperoleh data konsumen CV. Stella Catering Medan berdasarkan jumlah pesanan yang diterima setiap bulannya dari bulan Oktober 2020 sampai dengan Maret 2021.

Masalah inovasi juga berperan dalam menghambat tercapainya keberhasilan usaha CV. Stella Catering. Sulitnya berinovasi pada rasa makanan dan minuman pada CV. Stella Catering karena tidak memiliki sumber daya manusia yang berkompeten dalam hal melakukan inovasi rasa makanan dan minuman yang disajikan. Tidak dilakukannya inovasi rasa juga karena perusahaan sangat menjaga ciri khas dari rasa makanan dan minuman yang disajikan sehingga tidak sangat jarang dalam menciptakan rasa makanan dan minuman dengan rasa yang lebih fresh dan menggugah selera konsumen. Namun keputusan untuk tidak melakukan inovasi rasa sangat membuat konsumen bosen karena konsep dengan rasa makanan dan minuman yang terlalu monoton, sehingga konsumen mencari dari perusahaan lain dari perusahaan yang memberikan penawaran lebih. Apalagi peneliti juga memperoleh informasi dari salah satu CV. Stella Catering bahwa makanan yang disajikan memang cukup bagus, tapi konsepnya hampir sama dengan konsep perusahaan lain bahkan rasa makanannya masih tertinggal jauh dari beberapa usaha katering lainnya yang pernah dicoba. 


\subsection{Rumusan Masalah}

Menurut Sugiyono (2016:35) rumusan masalah merupakan suatu pertanyaan yang akan dicarikan jawabannya melalui pengumpulan data”. Maka berdasarkan batasan masalah yang telah ditentukan diatas dapat dirumuskan permasalahan yaitu:

1) Apakah karakteristik kewirausahaan berpengaruh positif dan signifikan terhadap keberhasilan usaha mikro Pada CV. Stella Catering Medan?

2) Apakah inovasi rasa berpengaruh positif dan signifikan terhadap keberhasilan usaha mikro Pada CV. Stella Catering Medan?

3) Apakah karakteristik kewirausahaan dan inovasi rasa berpengaruh positif dan signifikan terhadap keberhasilan usaha mikro Pada CV. Stella Catering Medan?

4) Seberapabesar pengaruh karakteristik kewirausahaan dan inovasi rasa terhadap keberhasilan usaha mikro Pada CV. Stella Catering Medan?

\subsection{Batasan Masalah}

Menurut Arikunto (2016:22), batasan masalah merupakan bagian dari kebutuhan seseorang untuk dipecahkan". Maksudnya ialah fokus pada ruang lingkup yang diteliti sampai menimbulkan jawaban dalam diri seseorang yang mencari permasalahan. Dalam peneitian ini penulis membatasi permasalahan pada Pengaruh Karakteristik Kewirausahaan dan Inovasi Rasa Terhadap Keberhasilan Usaha Mikro Pada CV. Stella Catering Medan.

\subsection{Tujuan Penelitian}

Menurut

Arikunto

mengatakan, tujuan penelitian adalah rumusan kalimat yang menunjukan adanya sesuatu hal yang diperoleh setelah penelitian selesai Penelitian dilakukan tentunya karena ada hal yang akan dituju. Berdasarkan rumusan masalah diatas maka tujuan dan penelitian ini adalah:

1) Untuk mengetahui pengaruh karakteristik kewirausahaan terhadap keberhasilan usaha mikro Pada CV. Stella Catering Medan.

2) Untuk mengetahui pengaruh inovasi rasa terhadap keberhasilan usaha mikro Pada CV. Stella Catering Medan.
3) Untuk mengetahui Pengaruh Karakteristik Kewirausahaan dan Inovasi Rasa Terhadap Keberhasilan Usaha Mikro Pada CV. Stella Catering Medan.

4) Untuk mengetahui seberapabesar pengaruh Karakteristik Kewirausahaan dan Inovasi Rasa Terhadap Keberhasilan Usaha Mikro Pada CV. Stella Catering Medan.

\section{Metode Penelitian \\ 2.1 Populasi}

Sugiyono (2016:80) menjelaskan, populasi adalah wilayah generalisasi yang terdiri atas objek yang mempunyai kualitas dan karakteristik tertentu yang ditetapkan oleh penelitian untuk dipelajari dan kemudian ditarik kesimpulannya. Dalam penelitian ini yang menjadi populasi adalah Konsumen $\mathrm{CV}$. Stella Catering dari bulan Oktober 2020 sampai dengan bulan Maret 2021 yaitu sebanyak 55 orang.

\subsection{Sampel}

Sugiyono (2016:81) menjelaskan, sampel adalah bagian dan jumlah dan karakteristik yang dimiliki oleh populasi tersebut. Karena populasi penelitian ini sedikit yaitu kurang dari 100 maka teknik penarikan sampel penelitian ini menggunakan teknik sampling jenuh yaitu teknik penentuan sampel dengan cara mengambil seluruh anggota populasi sebagai responden atau sampel. Penelitian ini mengambil sampel secara keseluruhan dari total populasi yaitu sebanyak 55 orang.

\subsection{Uji Normalitas}

Uji Normalitas adalah sebuah uji yang dilakukan dengan tujuan untuk menilai sebaran data pada sebuah kelompok data atau variabel, apakah sebaran data tersebut berdistribusi normal ataukah tidak. Uji Normalitas berguna untuk menentukan data yang telah dikumpulkan berdistribusi normal atau diambil dan populasi normal. Metode klasik dalam pengujian normalitas suatu data tidak begitu rumit. Untuk melihat apakah data terdistribusi normal atau tidak, penulis menggunakan uji analisis Kolmogorov-Smirnov dengan kriteria nilai signifikansi harus lebih besar dan 0,05 untuk dapat dikatakan data terdistribusi normal. Berikut adalah hasil ujinya: 
Tabel 1.Hasil Uji Normalitas Data

One-Sample Kolmogorov-Smirnov Test

\begin{tabular}{|l|r|r|}
\hline & & Unstandardized Residual \\
\hline & & 55 \\
MeanNormal Parameters & Std. & .0000000 \\
& Deviation & 4.46523181 \\
Most Extreme & Absolute & .097 \\
& Differences & .097 \\
& Positive & -.063 \\
& Negative & .720 \\
Kolmogorov-Smirnov ZAsymp. Sig. (2- & .678 \\
tailed) & & \\
\hline
\end{tabular}

a. Test distribution is Normal.

b. Calculated from data. Sumber: Output SPSS, 2021.

Tabel 1, menujukkan menunjukkan bahwa bonus, tunjangan dansemangat kerja normal karena probability value > 0,05 yaitu sebesar 0,678 .

\subsection{Uji Multikolinearitas}

Uji multikolinearitas bertujuan untuk menguji apakah dalam metode regresi yang terbentuk ada korelasi yang tinggi atau sempurna di antara variabel bebas atau tidak. Jika dalam model regresi yang terbentuk terdapat korelasi yang tinggi atau sempurna di antara variabel bebas maka model regresi tersebut dinyatakan mengandung gejala multikolinearitas.

Salah satu cara melihat ada atau tidaknya gejala mulikolinearitas adalah dengan melihat mlai Tolerance dan Variance Inflating Factor (VIF). Jika nilai Tolerance $<0,1$ dan VIF $>10$ dapat dıindıkasıkan adanya multikolinearitas begitu juga sebaliknya. Berikut adalah hasil uji multikolinieritas yang diuji menggunakan SPSS versi 21.00 for windows.

Tabel 2. Hasil Uji MultikolinearitasCoefficients ${ }^{\mathrm{a}}$

\begin{tabular}{|c|c|c|}
\hline \multirow[t]{2}{*}{ Model } & \multicolumn{2}{|l|}{$\begin{array}{l}\text { Collinearity } \\
\text { Statistics }\end{array}$} \\
\hline & Tolerance & VIF \\
\hline $\begin{array}{ll} & \text { (Constant) } \\
1 & \text { Karakter } \\
& \text { Kewirausahaan } \\
& \text { Inovasi Rasa }\end{array}$ & $\begin{array}{r}.856 \\
.856\end{array}$ & $\begin{array}{l}1.168 \\
1.168\end{array}$ \\
\hline
\end{tabular}

Berdasarkan tabel 4.37 dapat dilihat pada tabel Coefficientsa kolom tolerance dan VIF, nilai VIF untuk variabel karakterisik kewirausahaan dan inovasi rasa adalah 1,168 dengan tolerance 0,420. Dengan melihat VIF (Variance Infloating Factor) variabel karakteristik kewirausahaan dan inovasi rasa sebesar 1,168 lebih kecil dari 10 dan nilai tolerance yaitu 0,856 berada di atas 0,1 maka pada model regresi yang terbentuk tidak terjadi gejala multikolinearitas.

\subsection{Uji Heteroskedasitas}

Heteroskedastisitas berarti ada varian variabel pada model regresi yang tidak sama (konstan). Sebaliknya, jika varian variabel pada model regresi memiliki nilai yang sama (konstan) maka disebut dengan homokedastisitas.

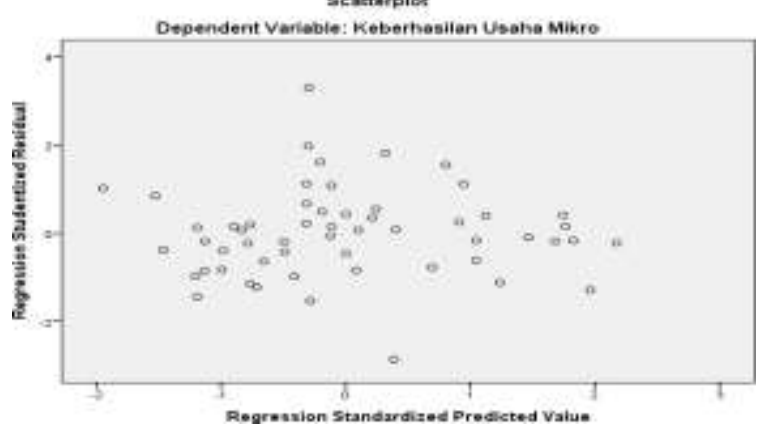

Gambar 1. Hasil Uji Asumsi Heteroskedasitas Scatterplot 
Berdasarkan tampilan pada scatterplot terlihat bahwa plot menyebar secara acak di atas maupun di bawah angka nol pada sumbu Regression Studentized Residual. Oleh karena itu maka berdasarkan uji heteroskedastisitas menggunakan metode analisis grafik, pada model regresi yang terbentuk dinyatakan tidak terjadi gejala heteroskedastisitas.

\section{Hasil Dan Pembahasan}

3.1Analisis Regresi Berganda
Menurut Untuk mengetahui pengaruh antara variabel karakteristik kewirausahaan $\left(\mathrm{X}_{1}\right)$ dan inovasi rasa $\left(\mathrm{X}_{2}\right)$ dengan variabel keberhasilan usaha mikro (Y) pada CV. Stella Catering Medan adalah kuat, maka digunakan analisis regresi linier berganda. Dimana variabel bebasnya adalah bonus $\left(\mathrm{X}_{1}\right)$ dan tunjangan $\left(\mathrm{X}_{2}\right)$ serta variabel terikatnya adalah semangat kerja (Y). Berikut ini adalah hasil uji regresi linear berganda yang diperoleh dengan menggunakan SPSS versi 21.00 for windows dapat dilihat pada tabel berikut:

Tabel 3. Hasil Uji Regresi Linear BergandaCoefficients ${ }^{\mathrm{a}}$

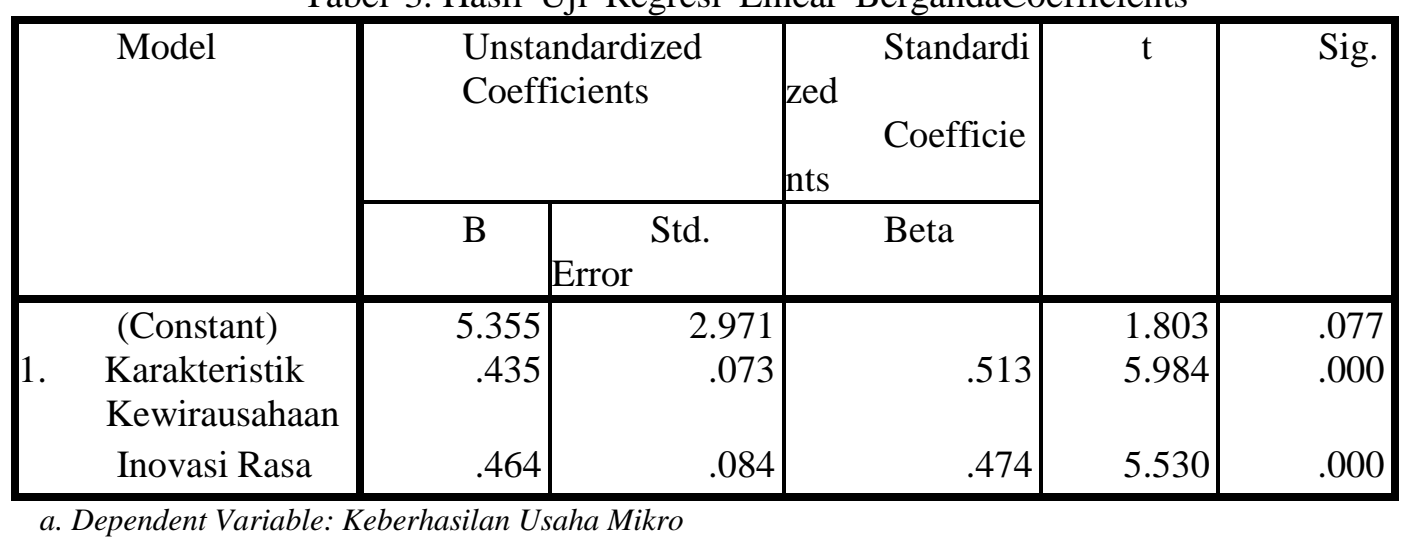

Berdasarkan tabel 4.40 maka persamaan analisis linear berganda dalam penelitian ini adalah:

$$
\mathrm{Y}=5,355+0,435 \mathrm{X} 1+0,464 \mathrm{X} 2
$$

1) Berdasarkan Nilai Konstanta (a) sebesar 5,355 menunjukkan bahwa tanpa adanya variabel karakterisitik kewirausahaan dan inovasi rasa besar nilai keberhasilan usaha mikro pada CV. Stella Catering Medan.

2) Nilai koefisien karakteristik kewirausahaan (X1) sebesar 0,435 bernilai positif, menunjukkan bahwa variabel karakteristik kewirausahaan berpengaruh positif terhadap keberhasilan usaha mikro pada CV. Stella Catering Medan. Artinya bahwa jika karakteristik kewirausahaan mengalami peningkatan dan penambahan sebesar 1 satuan maka keberhasilan usaha mikro akan meningkat sebesar 0,435 atau $43,5 \%$.

3) Nilai koefisien inovasi rasa (X2) sebesar 0,464 bernilai positif, menunjukkan bahwa variabel inovasi rasa berpengaruh positif terhadap keberhasilan usaha mikro pada CV. Stella Catering Medan. Artinya bahwa jika inovasi rasa mengalami peningkatan atau penambahan sebesar 1 satuan, maka inovasi rasa akan meningkat sebesar 0,464 atau $46,4 \%$.

\subsection{Hasil Uji Hipotesis \\ 3.2.1. Uji t}

Uji t dilakukan untuk mengetahi pengaruh karakteristik kewirausahaan dan inovasi rasa terhadap keberhasilan usaha mikro pada CV. Stella Catering Medan. Uji t dilakukan untuk membuktikan hipotesis dengan membandingkan $t_{\text {hitung }}$ dengan $t_{\text {tabel }}$ Apabila $t_{\text {hitung }}$ $>\mathrm{t}_{\text {tabel }}$ dan nilai signifikansi $<\alpha 0,05$, maka dikatakan pengaruhnya signifikan, dan apabila $\mathrm{t}_{\text {hitung }}<\mathrm{t}_{\text {tabel }}$ dan nilai signifikansi $>\alpha 0,05$, maka dikatakan pengaruhnya tidak signifikan. 
Tabel 4. Hasil Uji t Coefficients ${ }^{\mathrm{a}}$

\begin{tabular}{|c|c|c|c|c|c|}
\hline \multirow[t]{2}{*}{ Model } & \multicolumn{2}{|c|}{$\begin{array}{l}\text { Unstandardized } \\
\text { Coefficients }\end{array}$} & $\begin{array}{l}\text { Standardized } \\
\text { Coefficients }\end{array}$ & \multirow[t]{2}{*}{$\mathrm{t}$} & \multirow[t]{2}{*}{ Sig. } \\
\hline & B & Std. Error & Beta & & \\
\hline (Constant) & 5.355 & 2.971 & & 1.803 & .077 \\
\hline Karakteristik & .435 & .073 & .513 & 5.984 & .000 \\
\hline Inovasi Rasa & .464 & .084 & .474 & 5.530 & .000 \\
\hline
\end{tabular}

a. Dependent Variable: Keberhasilan Usaha MikroSumber: Hasil Output SPSS, 2021.

Pada tabel 4.41 , diperoleh nilai $\mathrm{t}_{\text {hitung. }}$. Nilai $\mathrm{t}_{\text {hitung }}$ tersebut selanjutnya dibandingkan dengan nilai $t_{\text {tabel }}$ pada $\alpha=0,05$. Nilai $t_{\text {tabel }}$ pada $\mathrm{df}$ (n-k) dimanan adalah banyaknya sampel dan $\mathrm{k}$ adalah banyaknya variabel baik variabel bebas maupun terikat, maka 55-3 $=52$. Pada df 52 dengan $\alpha=0,05$ nilai $t$ adalah 1,674.

Berdasarkan tabel 4.41, diperoleh nilai $t_{\text {hitung }}$ variabel karakteristik kewirausahaan sebesar 5,984 dengan signifikansi 0,000. Sedangkan nilai $t_{\text {tabel }}$ sebesar 1,674. Karena nilai $t_{\text {hitung }}$ $(5,984)>t_{\text {tabel }}(1,674)$ dan nilai signifikansi $0,000<0,05$, maka $\mathrm{H}_{\mathrm{a}}$ diterima dan $\mathrm{H}_{0}$ ditolak. Artinya karakteristik kewirausahaan berpengaruh signifikan terhadap keberhasilan usaha mikro pada CV. Stella Catering Medan.
Berdasarkan tabel 4.41 , diperoleh nilai $\mathrm{t}_{\text {hitung }}$ variabel tunjangan sebesar 5,530 dengan signifikansi 0,000 . Sedangkan nilai $t_{\text {tabel }}$ sebesar 1,674. Karena $t_{\text {hitung }}(5,530)>t_{\text {tabel }}(1,674)$ dan nilai signifikansi $0,000<0,05$, maka $\mathrm{Ha}$ diterima dan $\mathrm{H}_{0}$ ditolak. Artinya inovasi rasa berpengaruh signifikan terhadap keberhasilan usaha mikro pada CV. Stella Catering Medan.

\subsubsection{Uji F}

Anova atau analisis varian merupakan uji koefisien regresi secara bersama- sama (uji F) untuk menguji signifikansi pengaruh beberapa variabel independen terhadap variabel dependen. Hasil uji F dapat dilihat pada tabel berikut:

Tabel 5. Hasil Uji F ANOVA ${ }^{\mathrm{a}}$

\begin{tabular}{|l|l|l|l|l|l|l|}
\hline Model & $\begin{array}{l}\text { Sum of } \\
\text { Squares }\end{array}$ & df & $\begin{array}{l}\text { Mean } \\
\text { Square }\end{array}$ & F & Sig. \\
\hline \multirow{1}{*}{\begin{tabular}{ll|l|l|l|} 
Regression \\
Residual
\end{tabular}} & 2212.168 & 2 & 1106.084 & 53.421 & $.000^{\mathrm{b}}$ \\
& 1076.668 & 52 & 20.705 & & \\
\hline & Total & 3288.836 & 54 & & & \\
\hline
\end{tabular}

a. Dependent Variable: Keberhasilan Usaha Mikro

b. Predictors: (Constant), Inovasi Rasa, Karakter Kewirausahaan

Pada tabel 4.42 diperoleh nilai $\mathrm{F}_{\text {hitung }}$ bernilai positif sebesar 53,421 dengan signifikansi sebesar 0,000 sedangkan nilai $\mathrm{F}_{\text {tabel }}$ sebesar 2,78. Dengan demikian $\mathrm{F}_{\text {hitung }}=53,421>\mathrm{F}_{\text {tabel }}=$ 2,78 dan signifikansi $0,000<0,05$. Artinya variabel karakteristik kewirausahaan dan inovasi rasa secara simultan berpengaruh positif dan signifikan terhadap keberhasilan usaha mikro pada CV. Stella Catering Medan.

Tabel 6.Hasil Uji Koefisien Determinasi Model Summary ${ }^{\mathrm{b}}$

\begin{tabular}{|c|c|c|c|c|}
\hline Model & $\mathrm{R}$ & R Square & Adjusted R Square & Std. Error of the Estimate \\
\hline 1 & $.820^{\mathrm{a}}$ & .673 & .660 & 4.550 \\
\hline
\end{tabular}

a. Predictors: (Constant), Inovasi Rasa, Karakter Kewirausahaan

b. Dependent Variable: Keberhasilan Usaha Mikro 
1) R menunjukkan korelasi sederhana, yaitu karakteristik kewirausahaan daninovasi rasa terhadap keberhasilan usaha mikro adalah sebesar $0,820 \%$. Artinya hubungannya sangat kuat, semakin besar $\mathrm{R}$ berarti hubungannya semakin kuat.

2) $R$ square $\left(\mathrm{R}^{2}\right)$ atau kuadrat $\mathrm{R}$ menunjukkan koefisien determinasi adalah sebesar 0,673 artinya persentase karakteristik kewirausahaan dan inovasi rasa terhadap keberhasilan usaha sebesar 0,673 atau $67,3 \%$, sedangkan sisanya sebesar $32,7 \%$ dipengaruhi oleh variabel lain yang tidak diteliti oleh penelitianini.

3) Adjusted $R$ Square merupakan nilai $R^{2}$ yang disesuaikan sehingga gambarnya lebih mendekati mutu penjajakan model dalam populasi. Dari tabel 4.43 dapat dibaca bahwa Adjusted $R$ Square $\left(\mathrm{R}^{2}\right)$ adalah 0,660 atau $66 \%$, sedangkan sisanya $34 \%$ dijelaskan oleh faktor lain.

4) Standart Error of The Estimated adalah ukuran kesalahan prediksi. Standart Error Of The Estimated juga bisa disebut standart deviasi. Dalam kasus ini nilainya sebesar 4,550\%. Semakin kecil standart deviasi berarti model semakin baik.

\section{Hasil Analisa}

\subsection{Pengaruh Karakteristik Kewirausahaan Terhadap Keberhasilan Usaha}

Nilai koefisien karakteristik kewirausahaan $\left(\mathrm{X}_{1}\right)$ sebesar 0,435 bernilai positif, menunjukkan bahwa variabel karakteristik kewirausahaan berpengaruh positif terhadap keberhasilan usaha mikro pada CV. Stella Catering Medan. Nilai $t_{\text {hitung }}$ variabel karakteristik kewirausahaan $(5,984)>t_{\text {tabel }}$ $(1,674)$ dan nilai signifikansi $0,000<0,05$, Artinya karakteristik kewirausahaan berpengaruh signifikan terhadap keberhasilan usaha mikro pada CV. Stella Catering Medan. Dapat disimpulkan bahwa Hipotesis (Ha.1): Diduga karakteristik kewirausahaan berpengaruh positif dan signifikan terhadap keberhasilan usaha mikro Pada CV. Stella Catering Medan "Diterima"

Hasil penelitian ini sejalan dengan penelitian Pradana (2019) yang berjudul "Pengaruh Karakteristik Wirausaha Terhadap Keberhasilan Usaha Pada Petani Lele di Kota Madiun" yang menunjukkan bahwa terdapat pengaruh yang signifikan antara Karakteristik Wirausaha terhadap Keberhasilan Usaha pada Petani Lele di Kota Madiun. Disimpulkan bahwa
Karakteristik Wirausaha dapat meningkatkan Keberhasilan Usaha. Bahri dan Arda (2019) juga dalam penelitiannya yang berjudul "Pengaruh Karakteristik Pengusaha Terhadap Keberhasilan Usaha Kecil Pada Kalangan Generasi Z" menemukan bahwa ada pengaruh signifikan karakteristik pengusaha pada keberhasilan usaha kecil mahasiwa UMSU.

\subsection{Pengaruh Inovasi Rasa Terhadap Keberhasilan Usaha}

Nilai koefisien inovasi rasa $\left(\mathrm{X}_{2}\right)$ sebesar 0,464 bernilai positif, menunjukkan bahwa variabel inovasi rasa berpengaruh positif terhadap keberhasilan usaha mikro pada CV. Stella Catering Medan. Nilai $t_{\text {hitung }}$ variabel inovasi rasa $(5,530)>t_{\text {tabel }}(1,674)$ dan nilai signifikansi $0,000<0,05$, Artinya inovasi rasa berpengaruh signifikan terhadap keberhasilan usaha mikro pada CV. Stella Catering Medan. Dapat disimpulkan bahwa Hipotesis $\left(\mathrm{H}_{\mathrm{a}} .2\right)$ : Diduga inovasi rasa berpengaruh positif dan signifikan terhadap keberhasilan usaha mikro Pada CV. Stella Catering Medan "Diterima".

\subsection{Pengaruh Karakteristik Kewirausahaan dan Inovasi Rasa Terhadap Keberhasilan Usaha}

Nilai $F_{\text {hitung }}$ bernilai positif sebesar 53,421 dengan signifikansi sebesar 0,000 sedangkan nilai $F_{\text {tabel }}$ sebesar 2,78. Dengan demikian $F_{\text {hitung }}$ $=53,421>\mathrm{F}_{\text {tabel }}=2,78$ dan signifikansi $0,000<$ 0,05. Artinya Hipotesis (Ha.3) Diduga karakteristik kewirausahaan dan inovasi rasa berpengaruh positif dan signifikan terhadap keberhasilan usaha mikro Pada CV. Stella Catering Medan "Diterima". Nilai Adjusted $R$ Square $\left(\mathrm{R}^{2}\right)$ adalah 0,660 menunjukkan bahwa karakteristik kewirausahaan dan inovasi rasa menjelaskan pengaruhnya terhadap keberhasilan usaha yaitu sebesar 0,660 atau $66 \%$, sedangkan sisanya $34 \%$ dijelaskan oleh variabel lain yang tidak diteliti dalam penelitian ini seperti variabel kreativitas, lingkungan eksternal dan strategi bertahan usaha.

Hasil penelitian ini sejalan dengan penelitian Ludiya dan Mulyana (2020) yang berjudul "Pengaruh Karakteristik Wirausaha dan Inovasi Terhadap Kinerja Usaha Pada UMKM Fashion di Kota Cimahi" yang menunjukkan bahwa Karakteristik wirausaha berpengaruh signifikan secara parsial terhadap kinerja usaha. Inovasi berpengaruh signifikan secara parsial terhadap kinerja usaha. Karakteristik wirausaha dan inovasi berpengaruh positif dan 
signifikan terhadap kinerja usaha secara simultan.

\section{Kesimpulan}

Berdasarkan hasil penelitian dan pembahasan pada bab sebelumnya, adapun penelitian ini disimpulkan sebagai berikut:

1. Nilai koefisien karakteristik kewirausahaan $\left(\mathrm{X}_{1}\right)$ sebesar 0,435 bernilai positif, menunjukkan bahwa variabel karakteristik kewirausahaan berpengaruh positif terhadap keberhasilan usaha mikro pada CV. Stella Catering Medan. Nilai $t_{\text {hitung }}$ variabel karakteristik kewirausahaan $(5,984)>t_{\text {tabel }}$ $(1,674)$ dan nilai signifikansi $0,000<0,05$, Artinya karakteristik kewirausahaan berpengaruh signifikan terhadap keberhasilan usaha mikro pada CV. Stella Catering Medan. Dapat disimpulkan bahwa karakteristik kewirausahaan berpengaruh positif dan signifikan terhadap keberhasilan usaha mikro Pada CV. Stella Catering Medan.

2. Nilai koefisien inovasi rasa $\left(X_{2}\right)$ sebesar 0,464 bernilai positif, menunjukkan bahwa variabel inovasi rasa berpengaruh positif terhadap keberhasilan usaha mikro pada CV. Stella Catering Medan. Nilai $t_{\text {hitung }}$ variabel inovasi rasa $(5,530)>t_{\text {tabel }}(1,674)$ dan nilai signifikansi $0,000<0,05$, Artinya inovasi rasa berpengaruh signifikan terhadap keberhasilan usaha mikro pada CV. Stella Catering Medan. Dapat disimpulkan inovasi rasa berpengaruh positif dan signifikan terhadap keberhasilan usaha mikro Pada CV. Stella Catering Medan.

3. Nilai $F_{\text {hitung }}$ bernilai positif sebesar 53,421 dengan signifikansi sebesar 0,000 sedangkan nilai $F_{\text {tabel }}$ sebesar 2,78. Dengan demikian $\mathrm{F}_{\text {hitung }}=53,421>\mathrm{F}_{\text {tabel }}=88 \quad 2,78$ dan signifikansi $0,000<0,05$. Artinya karakteristik kewirausahaan dan inovasi rasa berpengaruh positif dan signifikan terhadap keberhasilan usaha mikro Pada CV. Stella Catering Medan.

4. Nilai Adjusted $R$ Square $\left(\mathrm{R}^{2}\right)$ adalah 0,660 menunjukkan bahwa karakteristik kewirausahaan dan inovasi rasa menjelaskan pengaruhnya terhadap keberhasilan usaha yaitu sebesar 0,660 atau 66\%, sedangkan sisanya $34 \%$ dijelaskan oleh variabel lain yang tidak diteliti dalam penelitian ini seperti variabel kreativitas, lingkungan eksternal dan strategi bertahan usaha.

\section{DAFTAR PUSTAKA}

BUKU

Alma, B. (2020). Kewirausahaan (untuk

Mahasiswa dan Umum). Bandung: Alfabeta.

Arikunto, S. (2016). Prosedur Penelitian

Suatu Pendekatan Praktik. Jakarta: Rineka

Cipta.

Basrowi. 2016. Kewirausahaan Untuk

Darmanto dan Wardaya, S. (2016). Manajemen

Pemasaran. Ed. 1, Cet.1. Deepublih.

Yogyakarta.

Ghozali, I. (2018). Aplikasi Analisis

Multivariate dengan Program IBM SPSS.

Yogyakarta: Universitas Diponegoro.

Iskandar, D., Ramadhani, E., dan Bahri, S.

(2016). Kwirausahaan. Jakarta: Wacana

Media.

Martono, Nanang. 2015. Metode Penelitian

Kuantitatif. Jakarta. Rajawali Pers.

Sugiyono. (2016). Metode Penelitian

Kuantitatif Kualitatif $R \& B$. Bandung

Aflabeta.

Suryana. 2019. Kewirausahaan: Pedoman

Praktis, Kiatdan Proses Menuju Sukses. Bandung: Alfabeta.

Yusrita., Usman. H., \& Ridho. N. M.. (2015). Kewirausahaan (Membangun Usaha Sukses Sejak Dini). Bandung: Ciptapustaka Media.

\section{JURNAL}

Bahri, S., \& Arda, M. (2019). Pengaruh Karakteristik Pengusaha Terhadap Keberhasilan Usaha Kecil Pada Kalangan Generasi Z. 1(1), 265-273.

Dwiastanti, A., \& Mustapa, G. (2020). Pengaruh Karakteristik Wirausaha, Lingkungan Eksternal dan Strategi BErtahan UMKM dlama Menjaga Keberlangsungan Usaha di Musim Pandemi Covid 19. Business and Accounting Education Journal. 1(1), 229-237.

Firnalista, N., Nofialdi and Azriani, Z. (2020) „Impact of Entrepreneurial Characteristics and Access to Credit on Business Performance of Small Business (Case: Brown Sugar Processing in Agam District)", Indonesian Journal of Agricultural Research, 3(1), pp. 56-64.

Herlinawati, E. and Machmud, A. (2020) ,The effect of innovation on increasing business performance of SMEs in Indonesia", WSEAS Transactions on Business and Economics, 17, pp. 51-57. 
Ludiya, E., Mulyana, A. R., Ekonomi, F., Jenderal, U., \& Yani, A. (2020). Pengaruh karakteristik wirausaha dan inovasi terhadap kinerja usaha pada umkm fashion di kota cimahi Influence of entrepreneurial characteristics and innovation on business. 17(1), 113-120.

Pradana, A. E. (2019). Pengaruh Karakteristik Wirausaha Terhadap Keberhasilan Usaha Pada Petani Lele di Kota Madiun Alendra. Simba, 807-818.

Wiranawata, H. 2017. Pengaruh Inovasi dan Kreativitas Terhadap Keberhasilan Usaha Pada UMKM Kuliner di Kecamatan Baturaja Timur Kabupaten Ogan Komering Ulu. Journal of Chemical Information and Modelling, 53(9), 21-25. 